\title{
Fibrinolytic and fibrin stabilizing activity of synovial membranes
}

\author{
R. BACH ANDERSEN AND J. GORMSEN \\ From the Department of Physical Medicine, University Hospital, Copenhagen, and the Coagulation Laboratory, \\ Medical Department, Sundby Hospital, Copenhagen
}

Most tissues exhibit fibrinolytic activity because of their content of plasminogen activator (Albrechtsen, 1958; Astrup and Stage, 1952; Pandolfi, Nilsson, Robertson, and Isacson, 1967; Sayers, Tyler, and Lack, 1965). This activity might be demonstrated by applying the tissue itself or a tissue extract on a fibrin plate (Astrup and Permin, 1947; Caughey and Highton, 1967) or by the histiochemical fibrin slide technique (Todd, 1959).

The activity appears, as is shown by the "fibrinolysis autograph" technique, to be connected to the endothelium of veins and venules and of pulmonal arteries (Todd, 1964; Warren, 1964), although blood vessels may not be the only source of tissue activator activity (Astrup and Sjölin, 1958; Sayers and others, 1965). The "fibrinolysis autograph" technique has recently been used to demonstrate the tissue fibrin stabilizing factor. (Sayers and others, 1965).

Increased deposition of fibrin in tissue, in joint cavities, and on synovial membrane has been noticed in cases of rheumatoid arthritis (RA). The findings of Barnhart, Riddle, Bluhm, and Quintana (1967), Bluhm, Riddle, and Barnhairt (1966) Riddle, Bluhm, and Barnhart (1965), Dumonde and Glynn (1962), Glynn (1963), and Lack $(1964,1968)$ have led to the hypothesis that fibrin plays an important role in perpetuating the chronic inflammation of RA.

The purpose of this study has been to examine by means of the fibrinolysis autograph technique the plasminogen activator activity in synovial membranes, and to test its ability to degrade isolated human fibrin, fibrin from the plasma of patients with active RA, and fibrin from normal plasma, and also to test the fibrin stabilizing activity of the membranes by their ability to stabilize human fibrin deprived of the fibrin stabilizing factor (FSF).

\section{Material and methods}

\section{MATERIALS}

\section{Synovial membranes}

These were obtained from the knee joints of twenty patients with RA undergoing synovectomy. Fifteen had 'classical' and the 'definite' RA (Ropes, Bennett, Cobb, Jacox, and Jessar, 1959), three had Still's disease, and one had arthritis complicating ulcerative colitis. Synovial membranes were also obtained from the knee joints of five patients undergoing synovectomy because of monoarthritis, two because of osteoarthritis, and ten patients undergoing meniscectomy.

The specimens were stored into airtight boxes at $-20^{\circ} \mathrm{C}$. The activity of RA was assessed according to Lansbury (1966), except for strength of grip. The clinical characteristics of the patients are summarized in the Table.

\section{Thrombin}

Human preparation from A. G. Behringwerke, MarburgLahn. Fresh dilutions (20 units per ml. 0.9 per cent. $\mathrm{NaCl}$ ) have been used.

\section{Fibrinogen}

Lyophilized human fibrinogen, grade L, AB Kabi, Stockholm. A fresh solution (1 per cent.) in Michaelis barbital-sodium acetate buffer $(0.14 \mathrm{M} ; \mathrm{pH} 7.4)$ was used for coating the microslides. This fibrinogen, which is contaminated with plasminogen and FSF was separated biologically from plasminogen and FSF by column chromatography (Gormsen, 1970) and kept lyophilized. A stock solution of 1 per cent. in Michaelis buffer was used.

Plasma (1 part 3.8 per cent. trisodium citrate, 9 parts blood, centrifuged at 1500 r.p.m. for 15 minutes)

This came from a patient with classical RA stage 3 (Steinbrocker, Traeger, and Batterman, 1949) with a clinical index of 120 and a fibrinogen concentration of $850 \mathrm{mg} . / 100 \mathrm{ml}$. (Plasma I) and from a healthy person with normal sedimentation rate, normal serum protein parameters, and a fibrinogen concentration of $270 \mathrm{mg}$./ $100 \mathrm{ml}$. (Plasma II), were used for coating in some experiments. The fibrinogen concentration of the normal plasma was increased by adding human lyophilized fibrinogen (Kabi) to the final concentration of 1 per cent.

DEMONSTRATION OF TISSUE ACTIVATOR ACTIVITY Clean microslides were covered with a' small amount $0.06 \mathrm{ml}$. fibrinogen solution, clotted by adding $0.01 \mathrm{ml}$. thrombin, giving a $60-70 \mu$ thick fibrin film. The slides were kept in a moist chamber at room temperature $\left(21-24^{\circ} \mathrm{C}\right.$.) for 30 minutes. The frozen tissue was cut by a Slee cryostat (type $\mathrm{H}$ ) at a knife temperature of $-35^{\circ} \mathrm{C}$. and a cabinet 
temperature of $-25^{\circ} \mathrm{C}$. into $6-8 \mu$ thin sections, which were mounted on the fibrin film and placed for 30 minutes in a moist chamber at room temperature. By this technique the tissue will stick to the slide during the subsequent procedures. Four slides were prepared from each sample, one being fixed immediately by 3.6 per cent. formalin, while the remaining three were transferred to and incubated in another moist chamber $\left(37^{\circ} \mathrm{C}\right.$.) for 5,10 , and 20 minutes respectively. They were then fixed by formalin 3.6 per cent. and stained with Harris haematoxylin. Fibrinolytic activity is reflected by clear areas in the fibrin film and is graded according to the method of Pandolfi and others (1967). The fibrinolytic activity was also estimated on microslides covered with thrombinclotted Plasma I and II (see above). These plasmas have to be used freshly drawn in order to avoid technical difficulties. To exclude the possibility that fibrinolytic activity was due to plasmin or other proteases, tissue sections were tested on fibrin slides heated in a moist chamber to $85^{\circ} \mathrm{C}$. for 30 minutes, and on slides covered by fibrin obtained from $\epsilon$-aminocaproic acid (EACA) containing fibrinogen solution (EACA: final concentration: $\left.10^{-2} \mathrm{M}\right)$.

\section{DEMONSTRATION OF TISSUE FSF ACTIVITY}

Tissue sections obtained as described above are placed on microslides and covered with 'purified' (plasminogen and FSF free) fibrinogen, which is clotted by adding thrombin, making a fibrin film layer on the tissue. These are left for $\mathbf{3 0}$ minutes for consolidation, and afterwards incubated for 0,30 , and 60 minutes in a moist chamber at $37^{\circ} \mathrm{C}$., then immersed into $5 \mathrm{M}$ urea solution ( $\left.\mathrm{pH} 8.0\right)$

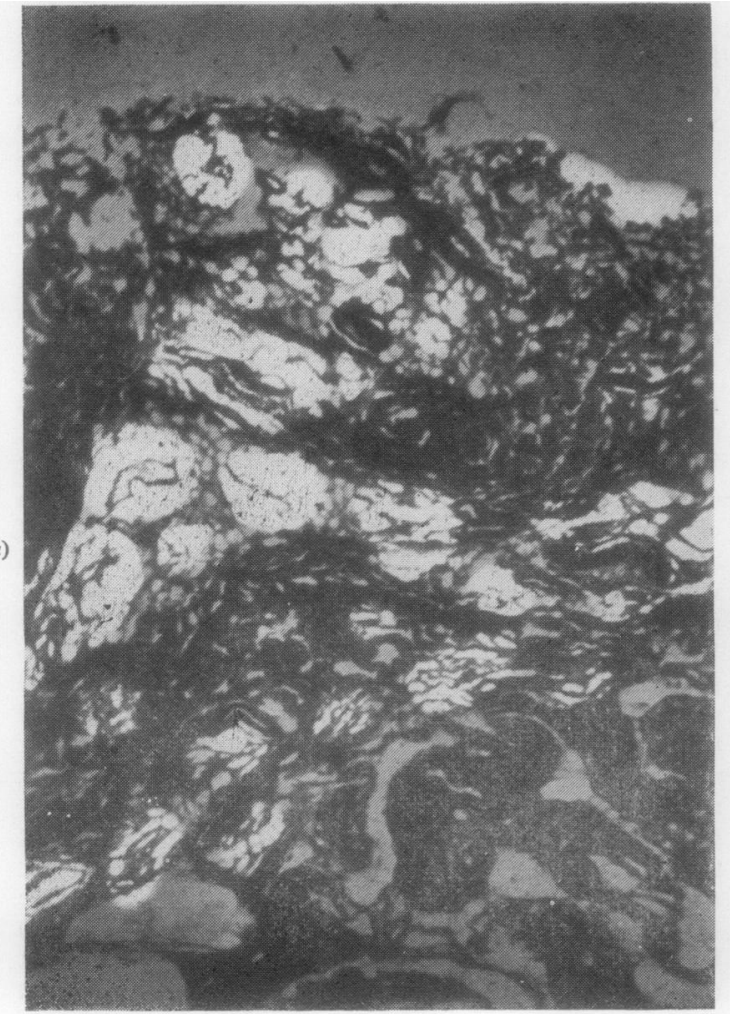

for 30 minutes, fixed, and stained as described above. Control experiments proved that 30 minutes' incubation in $5 \mathrm{M}$ urea sufficed to demonstrate whether stabilization had developed.

The results were graded as follows:

(1) no point, no fibrin left

(2) 1 point, traces of fibrin left,

(3) 2 points, part of tissue covered by fibrin,

(4) 3 points, tissue completely covered by fibrin.

The total number of points scored by three slides was used to define the extent of stabilization.

Microscopic examinations were always done on tissue sections cut immediately after the material used for the biochemical examinations, especially in order to omit necrotic areas.

\section{Results}

The fibrinolytic activity appears (Fig. 1) to be localized on the inside of the veins and venules, especially in the loose connective tissue between the fibrous capsules and the synovial membrane. In sections with high tissue activator activity, lysis is also seen corresponding to the superficial tissue underneath the synovial cells (Fig. 2), and the blood vessels are dilated and engorged in these sections, whereas vessels in sections with low fibrinolytic activity show thrombus formations and significant perivascular leucocyte infiltration. Similar appearances are seen in cases with monoarthritis or tears of the menisci. Lytic activity may be seen on the

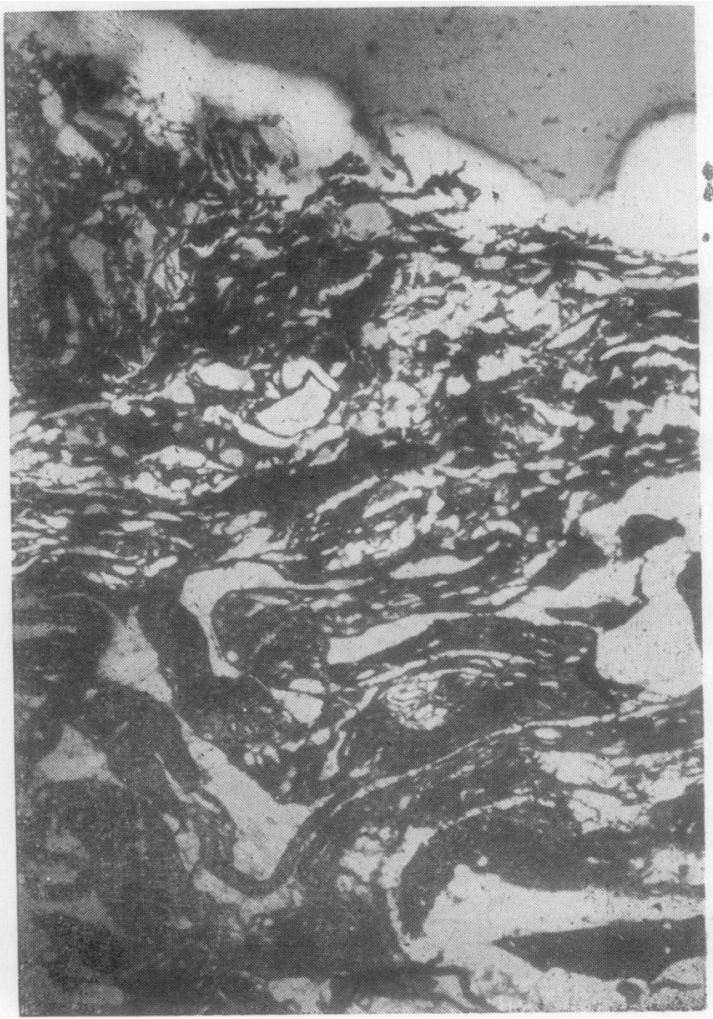




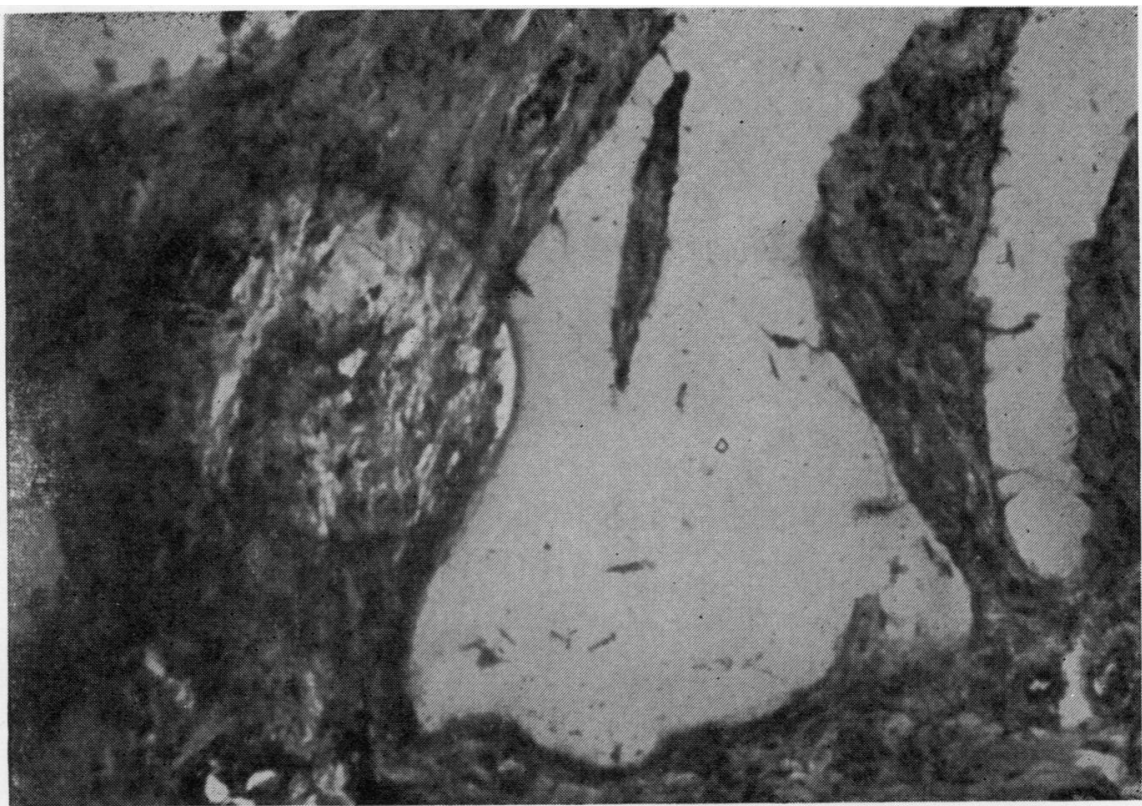

FIG. 2 Case 29. In cases with pronounced lytic activity this is also found in the superficial parts of the synovial membrane, surrounding a vessel. Harris haematoxylin. $\times 100$.

surface, but appears to be an extension of the activity localized in the smaller vessels. A distinct

(c)

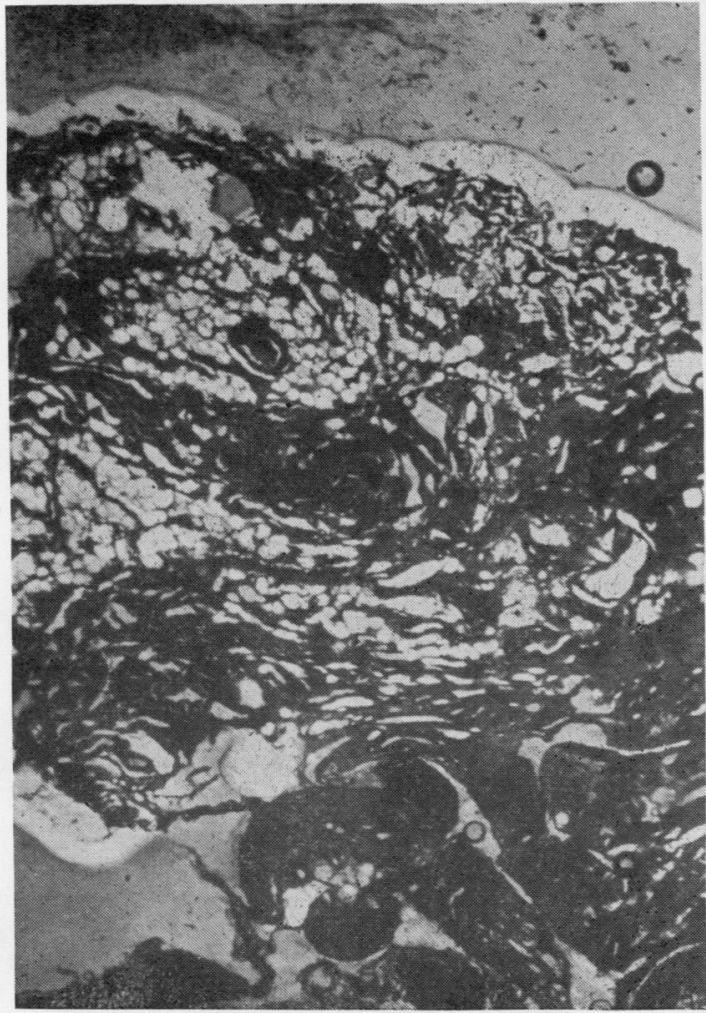

activity at the level of the synovial cells is not seen. Fibrin stabilizing activity is found in nearly all tissue sections. This activity is apparently not correlated to any specific cell, but is, when present, localized to the superficial part of the synovial membrane (Fig. 3, overleaf). The extension of stabilized fibrin increases with a longer incubation time until it covers all or nearly all the tissue.

In twelve cases of RA and in four of monoarthritis the tissue sections were also covered by Plasma I and Plasma II which were clotted by thrombin. No differences were seen whether the lytic activity was tested on standard fibrin slides or on slides covered by fibrin from Plasma I or II (Fig. 4, overleaf).

The lytic activity was not observed using fibrin slides pre-heated at $85^{\circ} \mathrm{C}$. for 30 minutes or slides with EACA containing fibrin.

Clinical characteristics, fibrinolytic activity, and fibrin stabilizing activity are compared in the Table (overleaf).

In general, a higher clinical index is combined by low lytic and high fibrin stabilizing activity. This correlation fails in Case 3. The lowest lytic activity

FIG. 1(a-c) Case 1. Plasminogen activator activity of tissue on standard fibrin microslides after 5, 10, and 20 minutes' incubation. The lytic activity appears in the clear zones and is most pronounced after 20 minutes.

The loose connective tissue is seen at the top and the villous formation at the bottom of the Figures. The activity is seen only in the area of connective tissue. Harris haematoxylin. $\times 25$. 
FIG. 3 Case 29. Fibrin stabilizing activity illustrated by persistence of fibrin (light area) on villous part of synovial membrane, after incubation in $5 M$ urea. In the right lower corner of the Figureno fibrin remains. Harrishaematoxylin. $\times 25$.
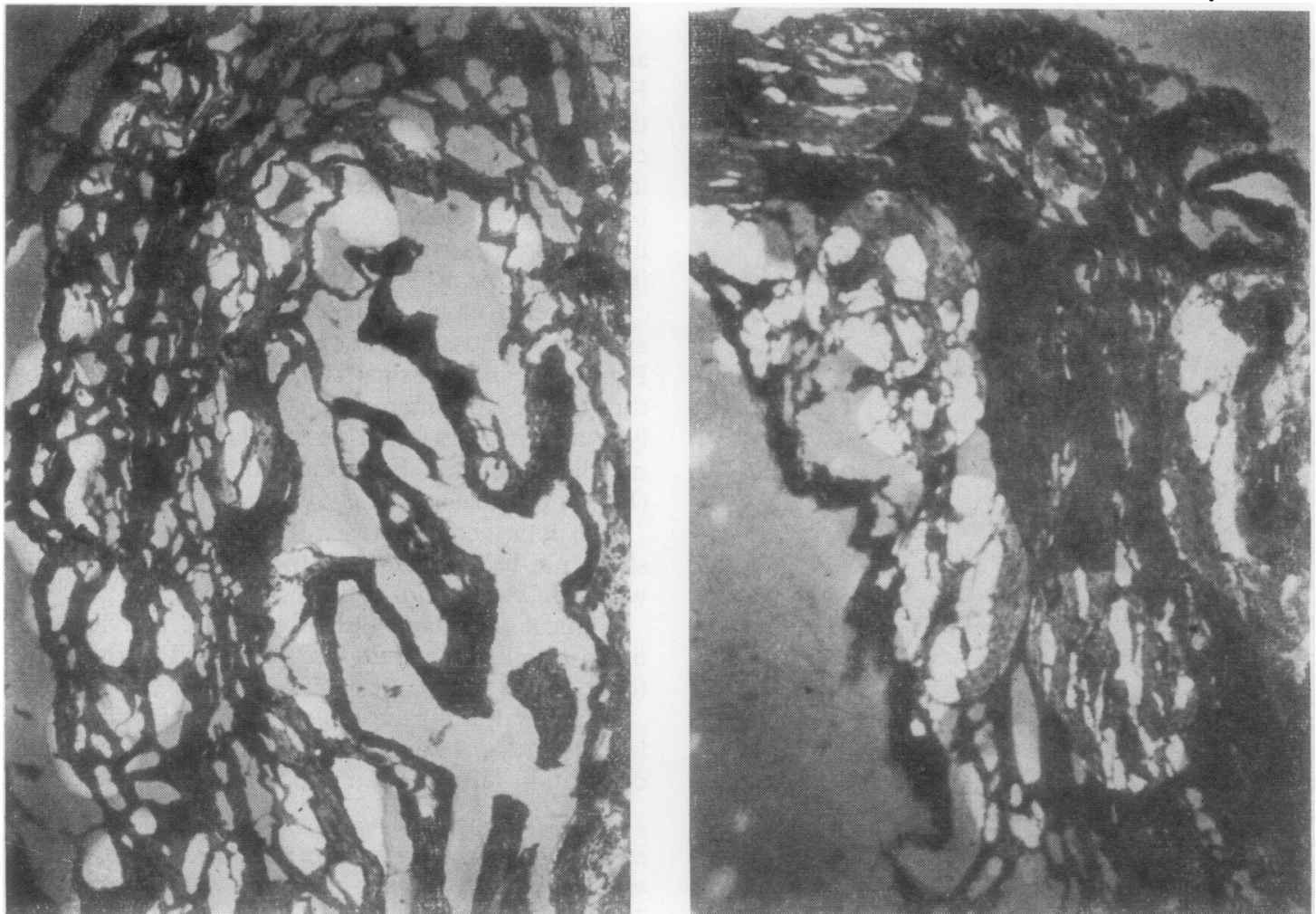

FIG. 4(a,b) Case 1. Plasminogen activator activity of tissue measured on microslides with fibrin film from Plasma I and Plasma II. Plasma I (left hand) is taken from a patient with severe RA, Plasma II (right hand) from a normal person. Incubation time 10 minutes. The lytic activity appears equal to that seen in Fig. 1. Harris haematoxylin. $\times 25$. 
Table Clinical characteristics, plasminogen activator activity, and fibrin stabilizing activity in 35 patients (Nos. 1 to 20 with rheumatoid arthritis)

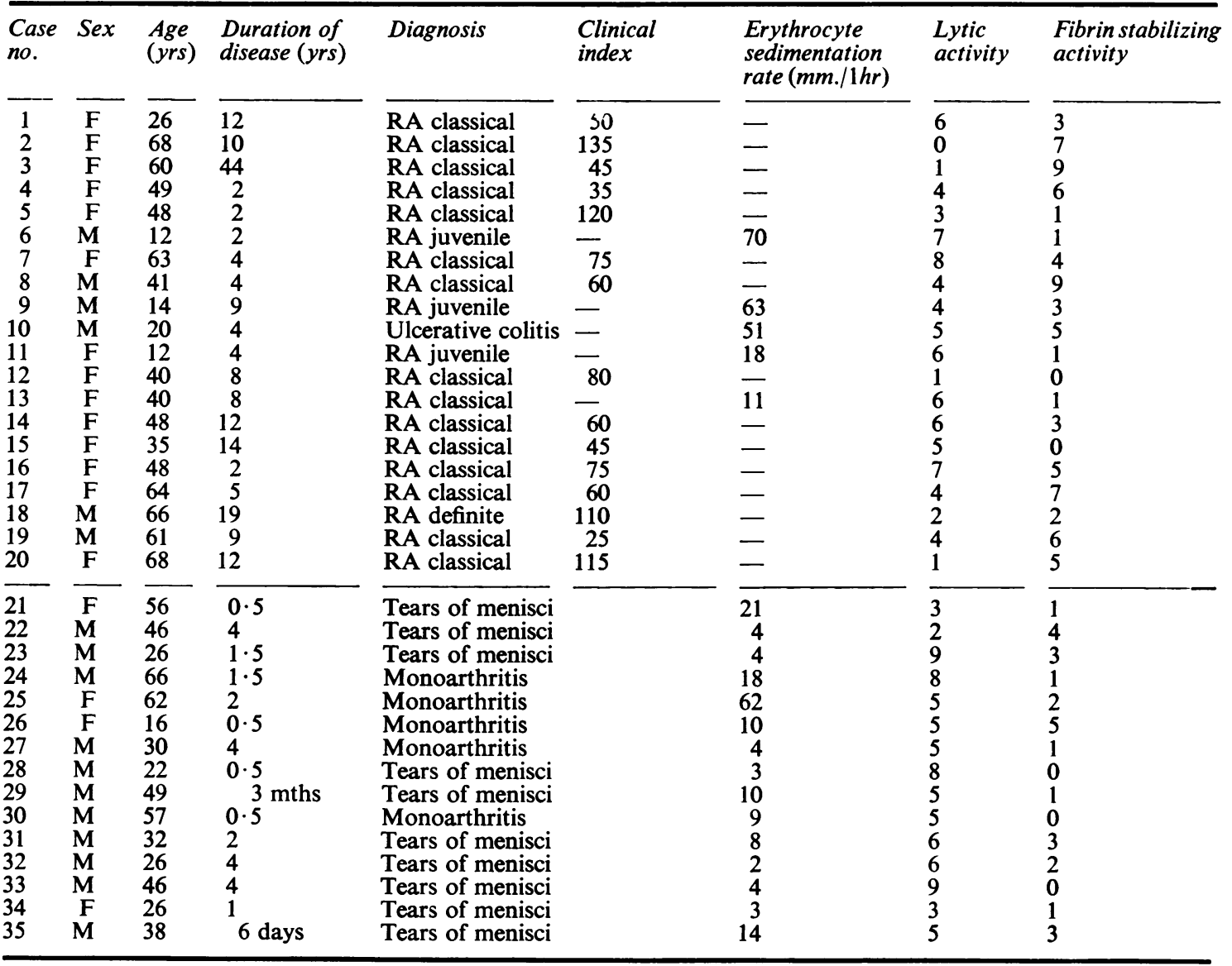

and the highest stabilizing activity is seen in patients with RA, but - taken as a group - no significant difference is seen between patients with RA, those with tears of the menisces, or those with monoarthritis.

\section{Discussion}

The normal liquefaction of fibrin in tissue depends partly on infiltration by leucocytes, resulting in phagocytosis and liberation of proteolytic enzymes, and partly on other enzymes such as plasmin, all combining in the degradation of fibrin into soluble peptides. The fibrinolytic activity found in extracts from human joint tissues is rather low compared with than from other human tissues, and this may result in a tendency to delay in tissue repair (Astrup, 1968).

The persistence of fibrin in RA may be due partly to the normal low fibrinolytic activity, and to a decrease in this activity, and partly to the formation of fibrin less susceptible to proteolytic enzymes.
Also the high kinin levels in synovial effusions from rheumatoid arthritis patients (Keele, 1969) may affect the normal balance between fibrin formation and fibrin dissolution.

This study has shown that plasminogen activator activity is especially pronounced in areas of connective tissue and many veins and venules, whereas less activity is seen in areas with fibrosis and vessels occluded by thrombi. Higher fibrin stabilizing activity corresponds to the superficial layer of the synovial membrane, where the fibrinolytic activity is low, as is shown by the persistence of fibrin at this level after incubating the material in $5 \mathrm{M}$ urea. This result may be due either to a low fibrinolytic activity at this level permitting the stabilization process to develop, or to a high content of fibrin stabilizing factor, resulting in more rapid formation of stabilized fibrin less susceptible to lytic activity (Gormsen, Fletcher, Alkjaersig, and Sherry, 1967). The lowest plasminogen activator activity and the highest fibrin stabilizing activity were found in synovial 
membranes from patients with RA. The very low activity was not due to necrosis. It should, however, be stressed that no significant differences have been demonstrated in fibrinolytic activity or fibrin stabilizing activity between synovial membranes from knee joints in cases of RA, monoarthritis, or meniscal tears taken as groups. Sayers and others (1965) suggested that a shift in the balance between plasminogen activator and fibrin stabilizing activity might be of decisive importance for the continuance of fibrin within the joints. Although the present study apparently supports this suggestion, it must be stressed that it is not known whether the biochemical changes demonstrated are primary or secondary.

Plasminogen activator activity was the same on films prepared with isolated human fibrin, or fibrin from a case of RA or fibrin from normal plasma. This may indicate that the substrate, fibrin, is equally susceptible to plasmin activity in all three systems.

\section{Summary}

Synovial membrane from twenty patients with RA, from five with monoarthritis undergoing synovec- tomy, and from ten undergoing meniscectomy, was examined for plasminogen activator activity and fibrin stabilizing activity by the "fibrinolysis autograph" technique. Fibrinolytic activity was found to be localized around and along the blood vessels, especially in loose connective tissue beneath the synovial membrane. The vessels in areas with high activity are dilated and engorged, whereas in areas with low activity they are occluded by thrombi, and pronounced leucocyte infiltration is present. Fibrin stabilizing activity is localized in the superficial part of the synovial membrane as shown by the persistence of stabilized fibrin at this level after incubation in urea. The lowest plasminogen activator activity and the highest fibrin stabilizing activity were seen in patients with RA, but the difference was not significant. Plasma from patients with RA had no inhibiting effect.

Our thanks are due to Prof. A. Bertelsen (Department U, University Hospital, Copenhagen) and to head surgeon H. Larsen (Department II, Orthopaedic Hospital, Copenhagen) for providing the biopsies.

This study has been supported by a grant from 'Rigsforeningen til gigtens bekæmpelse' and by 'Fonden for Storkøbenhavn, Grønland og Faeøerne'.

\section{References}

Albrechtsen, O. K. (1958) Scand. J. clin. Lab. Invest., 10, 91 (The fibrinolytic agents in saline extracts of human tissues).

Astrup, T. (1968) Biochem. Pharmacol., Suppl., ed. B. K. Forscher, p. 241 (Blood coagulation and fibrinolysis in tissue culture and tissue repair).

- AND Permin, P. M. (1947) Nature, (Lond.), 159, 681 (Fibrinolysis in the animal organism).

- AND Suölın, K. E. (1958) Proc. Soc. exp. Biol. (N.Y.), 97, 852 (Thromboplastic and fibrinolytic activity of human synovial membrane and fibrous capsular tissue).

— AND STAGE, A. (1952) Nature (Lond.), 170, 929 (Isolation of a soluble fibrinolytic activator from animal tissue).

Barnhart, M. I., Riddle, J. M., Bluhm, G. B., ANd Quintana, C. (1967) Ann. rheum. Dis., 26, 206 (Fibrin promotion and lysis in arthritic joints).

Bluhm, G. B., Riddle, J. M., AND BARnharT, M. I. (1966) Henry Ford Hosp. med. Bull., 14, 119 (Significance of fibrin and other particulates in rheumatoid joint inflammation).

Caughey, D. E., AND Highton, T. C. (1967) Ann. rheum. Dis., 26, 297 (Components of the fibrinolytic system in synovial joints).

Dumonde, D. C., AND GlynN, L. E. (1962) Brit. $\dot{J}$. exp. Path., 43, 373 (The production of arthritis in rabbits by an immunological reaction to fibrin).

GlynN, L. E. (1963) Bull. rheum. Dis., 14, 323 (Symposium on inflammation and role of fibrin in the rheumatic diseases).

GoRMSEN, J. (1970) Scand. J. Haemat. (In the press) (Fibrinolytic activity studied by haemagglutination inhibition immuno-assay).

—- Fletcher, A. P., Alkjaersig, N., And Sherry, S. (1967) Arch. Biochem. Biophys., 120, 654 (Enzymic lysis of plasma clots: the influence of fibrin stabilization on lysis rates).

Keele, C. A. (1969) Proc. roy. Soc. B., 173, 361 (Clinical and pathological aspects of kinins in man).

LACK, C. H. (1964) Brit. med. Bull., 20, 217 (Proteolytic activity and connective tissue).

- (1968) Biochem. Pharmacol., Suppl., ed. B. K. Forscher, p. 197 (Some biological and biochemical consequences of inflammation in connective tissue).

LANSBury, J. (1966) In 'Arthritis and Allied Conditions', ed. J. L. Hollander, 7th ed., p. 269 Lea and Febiger, Philadelphia (Methods for evaluating rheumatoid arthritis). 
Pandolfi, M., Nilsson, I. M., Robertson, B., AND Isacson, S. (1967) Lancet, 2, 127 (Fibrinolytic activity of human veins).

RIDDle, J. M., BluHM, G. B., AND BARNhART, M. I. (1965) J. reticuloendoth. Soc., 2, 420 (Interrelationships between fibrin, neutrophils and rheumatoid synovitis).

Ropes, M. W., Bennett, G. A., Cobb, S., Jacox, R. A., And Jessar, R. A. (1959) Ann. rheum. Dis., 18, 49 (1958 Revision of diagnostic criteria of rheumatoid arthritis).

SAYERS, D. C. J., Tyler, H. M., AND LACK, C. H. (1965) J. Path. Bact., 90, 551 (The histological demonstration of cytokinase and tissue fibrin stabilizing factor).

Steinbrocker, O., Traeger, C. H., AND Batterman, R. C. (1949) J. Amer. med. Ass., 140, 659 (Therapeutic criteria in rheumatoid arthritis).

ToDd, A. S. (1959) J. Path. Bact., 78, 281 (The histological localization of fibrinolysin activator).

- (1964) Brit. med. Bull., 20, 210 (Localization of fibrinolytic activity in tissues).

WARREN, B. A. (1964) Ibid., 20, 213 (Fibrinolytic activity of vascular endothelium).

\section{RÉSUMÉ}

L'activité fibrinolytique et l'activité stabilisatrice de la fibrine des membranes synoviales

La membrane synoviale de vingt malades atteints d'arthrite rhumatoïde, de cinq malades atteints de monoarthrite qui avaient subi la synovectomie et de dix qui avaient subi la méniscectomie, a été examinée pour démontrer l'activité du plasminogène activeur et l'activité stabilisatrice de la fibrine par la technique de 'l'autographie fibrinolytique'. L'activité fibrinolytique a été vue comme étant localisée autour et au long des vaisseaux sanguins, spécialement dans le tissu conjonctif lâche sous la membrane synoviale. Les vaisseaux des régions à grande activité sont dilatés et engorgés, tandis que ceux des régions à basse activité étaient obstrués par des thrombus, et une infiltration leucocytaire prononcée était présente. L'activité stabilisatrice de la fibrine est localisée dans la partie superficielle de la membrane synoviale, comme il est démontré par la persistance de la fibrine stabilisée à ce niveau après incubation dans l'urée. L'activité la plus basse du plasminogène activeur et l'activité la plus élevée de la fibrine stabilisatrice ont été vues chez les malades atteints d'arthrite rhumatoïde, mais cette différence n'était pas significative. Le plasma des malades atteints d'arthrite rhumatoïde n'avait aucune action inhibitrice.

\section{SUMARIO}

Actividad fibrinolítica $y$ actividad estabilizadora de la fibrina en las membranas sinoviales

La membrana sinovial de veinte pacientes con artritis reumatoide, la de cinco con monartritis sometidos a sinovectomía, y la de diez sometidos a meniscectomía, fue examinada en busca de actividad por activador plasminógeno y de actividad por fibrina estabilizadora, empleando la técnica de 'fibrinólisis autógrafa'. Se halló que la actividad fibrinolítica estaba localizada alrededor y a lo largo de los vasos sanguíneos, especialmente en tejido conectivo debajo de la membrana sinovial. En las zonas de gran actividad, los vasos están dilatadas y obstruidos, mientras que, en las zonas de poca actividad, están cerrados por trombos y se nota una pronunciada infiltración de leucocitos. La actividad estabilizadora de fibrina está localizada en la superficie de la membrana sinovial, como lo denota la persistencia de fibrina estabilizada a este nivel, después de incubación en úrea. La actividad más baja del activador plasminógeno y la actividad más alta de la fibrina estabilizante se notaron en pacientes con artritis reumatoide, pero la diferencia no era significativa. El plasma de pacientes con artritis reumatoide no tuvo efecto inhibitorio. 